\title{
Just Published!
}

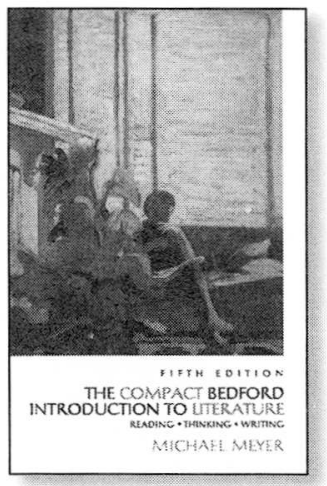

Ancillary Package:

- Resources for Teaching The COMPACt BeDFord INTRODUCtion to Literature, Fifth Edition (spiral-bound Instructor's Manual)

- Literature Aloud (CD or audiocassette)

- New Companion Web site at www.bedfordstmartins.com/bedlit
THE COMPACT BEDFORD INTRODUCTION TO LITERATURE Reading $\bullet$ Thinking $\bullet$ Writing Fifth Edition

Michael Meyer, University of Connecticut AUGUST 1999/PAPER/1650 PAGES

Ideally suited for the ways literature is taught today, The Compact Bedford Introduction to Literature offers all the distinctive features of Michael Meyer's bestselling introduction to literature in a shorter, less expensive paperback format.
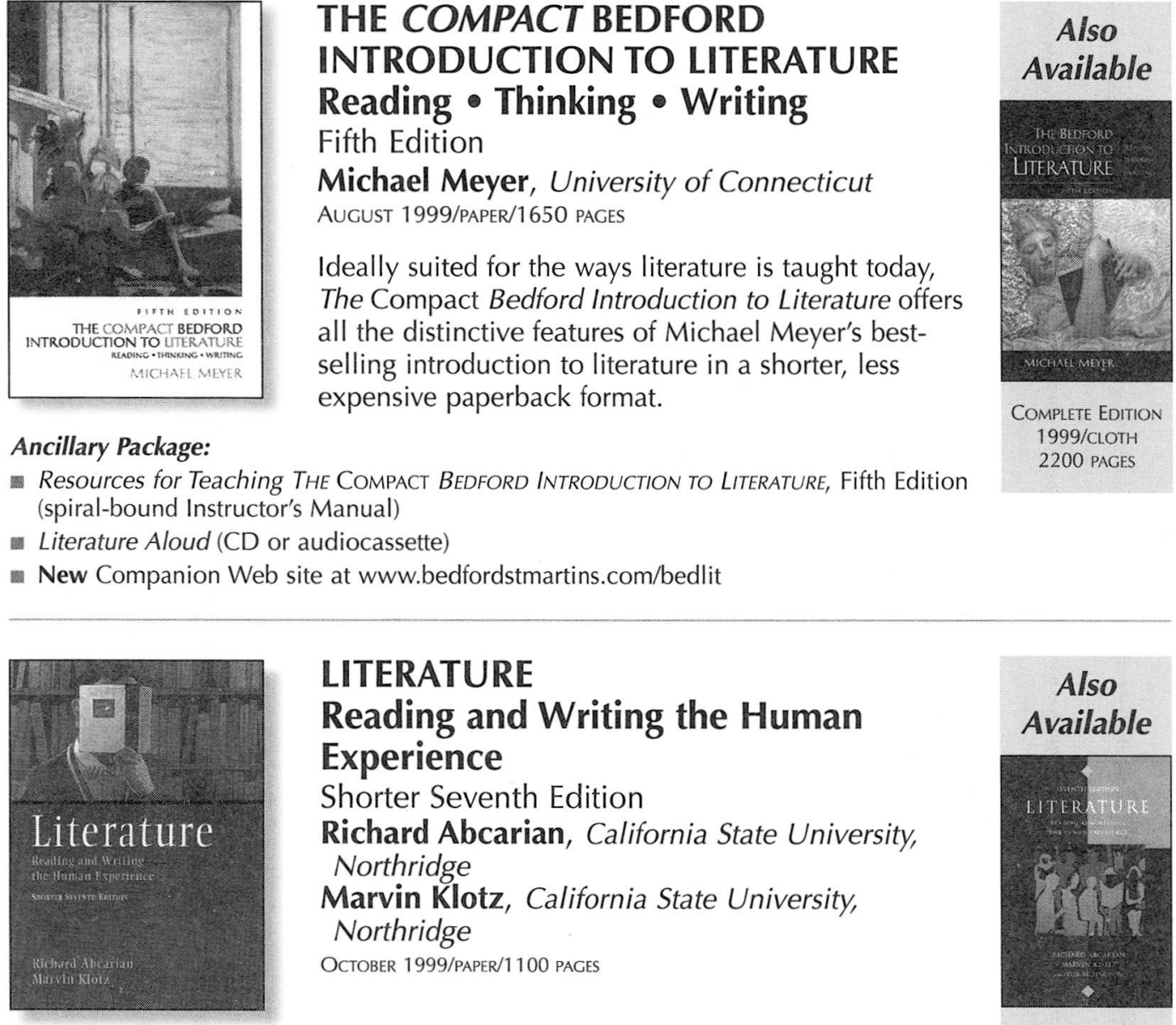

\section{LITERATURE}

Reading and Writing the Human

\section{Experience}

Shorter Seventh Edition

Richard Abcarian, California State University,

Northridge

Marvin Klotz, California State University,

Northridge

OCTOBER 1999/PAPER/1100 PAGES

Literature: Reading and Writing the Human Experience, Shorter Seventh

Edition, offers the most widely taught short stories, poems, plays, and essays

in a flexible thematic arrangement at a very low price - now with expanded

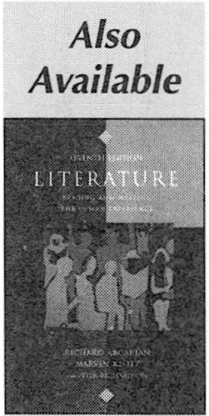

COMPLETE EDITION

1998/PAPER

1488 PAGES coverage of reading and writing about literature.

\section{Ancillary Package:}

- Resources for Teaching LITERATURE: READING AND WRITING THE HUMAN EXPERIENCE, (Instructor's Manual)

- Selected Poems from Literature: Reading and Writing the Human Experience (audiocassette)

- New Companion Web site at www.bedfordstmartins.com/experience_literature

\section{Ancillaries Developed for all BEDFORD/ST. MARTIN'S Literature Anthologies:}

- LitLinks - annotated research links for hundreds of authors - at www.bedfordstmartins.com/litlinks

- Robert Frost: Poems, Life, Legacy (CD-ROM)

- Videotapes of plays and stories featured in the anthologies available to qualified adopters

These titles can be combined for a discount with any titles from The Bedford/St. Martin's literary reprint series. 
Forthcoming in the

Fanuary issue of PMLA

\section{Special Topic: Rereading Class}

Introduction by Cora Kaplan

Five essays in pursuit of theories and practices in the

literatures of class:

representations of inclusion and exclusion, from trailer trash through life in the iron mills to the extinction of a species in the houses of mirth 